\title{
Annual Reports of the Schools of Drawing, Machine Design and Naval Architecture for the Sessions of 1902-1903.
}

THE DRAWING Schoor. -The season just closed has been the most successful one in the history of the drawing school, not only in the number of the students, but also in the regularity of their attendance and the earnestness of their purpose, and it is gratifying to realize the great benefit that they have received.

After this training in constructive drawing, they are able to perceive the relations between the lines and surfaces of solids, and this creates a desire to understand the mathematics of these relations and the scientific reasons why certain results follow certain combinations.

Hence the study of mechanical drawing stimulates an ambition for a scientific education, and paves the way for it in so far as it trains the mind to form tangible conceptions and to put these on paper in such manner as to be readily understood.

Another great good that the school is doing is in raising the standard of work. A good drawing can be made just as easily and as quickly as a poor one, if proper methods are used. The former is clear, quickly understood and read, and not apt to lead to errors. It is positive and absolute in all it says. The latter is just the reverse. Instead of being expensive, a good drawing is positively economical, because, if made by a properly trained man, its first cost need be no more than that of a bad one, and it saves in the time of those who have to work to it, and in the greater accuracy of the results attained.

The excellence of our course of instruction, and the good work done by the instructors, are best attested by the fact that the attendance at the spring term was only 6 per cent. less than at the winter term.

The Germantown Junction Branch School.-Mr. H. G. Norbom, Director of the Branch School at Germantown Junction, transmits the following report of its operations:

The attendance at the Branch School in the past year has been better than ever before, and it is very gratifying to see that the leading manufacturers surrounding the school appreciate the advantages in sending their young men for instruction.

There has been a steady increase every year. The school started some years ago with about a dozen scholars, while during the past year there were ninety-five scholars on the roll.

The results that have been shown by the scholars in neatness, accuracy and knowledge has been very gratifying to the instructors connected with the school, and a number of the young men have been helped to secure good positions with engineering concerns.

We beg to extend thanks to all who in one way or another have helped to make the Branch School successful.

$$
\begin{aligned}
& \text { WM. H. THORNE, } \\
& \text { Director. }
\end{aligned}
$$


The Following STUDENTS ARE ENTITLED TO HoNorable MHNTION :

In the Senior Mechanical Class.

Arthur C. Heintze, Leonard Hoerle, John McMonagle, Joseph Schenkel, Henry Stranahan, Jr., Harry W. Fox, J. Warren Smith, Howard W. Howitz, John Heenan,
Henry S. Cowell, Harry Hartranft, George M. Norman, J. Monroe Bowen, James McGettigan, Elmer B. Severs, Frederick Thomas Uezzell, Miles L. Tully, Edmund H. Berry,

Clarence Helmbold Wilson.

In the Intermediate Mechanical Class.

Herman Fink, Chester D. Thorpe, Walter D. Williams, Willian Wentzell, George Moxley, Henry G. Weaver, Albert F. Heeley, G. Hagstrom,

Harry Wickland, P. H. Erisman,

Daniel Sharp, James F. Bowen,

David Bowers, William E. Talbot,
Emil H. Schulze,

Samuel H. Blittersdorf, Albert Smith, James W. Marriott, George F. Kauffman, Harry Stange, Frank Roller, Charles F. Pfeiffer.

In the Junior Mechanical Class.

John Reilly, C. W. Leeds, Jr.

In the Architectural Class.

Harry Stull, John T. Rowley.

In the Free Hand Class.

John Talbot, Max J. Grocki.

The Folfowing STudents are Awarded Scholarships from THH B. H. BARTOI, FUND, ENTITLING THEM TO TICKETS FOR THE NEXT TERM :

Harry Wickland, George L. Gillingham, G. Hagstrom,
C. W. Leeds, Jr.,

Daniel Sharp,

David Bowers.

The Following Students Having attended a Fuld Course of Four Terms, with Satisfactory Results, are AWARded Certificates :

Edmund S. Allen, Edmund H. Berry, James F. Bowen,
Harry Hartranft, Leonard Hoerle, John McMonagle, 
George Blair, Chris. Buckius, Henry S. Cowell, Jesse Croft, Amos Fisler, Harry W. Fox, Frederick Froehlich, Otto Guenther, Louis T. Hall, John Heenan, Edward Hill, Howard W. Howitz,
Walter Russell, Henry Stranahan, Jr., J. Warren Smith, William F. Spaeth, Daniel Sharp, Harry Stull, Miles L. Tully, Frederick Thomas Uezzell, William Uhlhorn, Clarence Helmbold Wilson, Charles Wilson, James J. Woods.

\section{From the Branch School.}

George Quinn, J. Edward Lennon, Herman Wilmunder, Thomas Allison, Harry M. Cox, George Hutchby, Edwin Wright,
Matthew S. Esch, James Devlin, Jr., Harry Teunison, Franklin S. Reinhold, Richard Rigler, Charles Reinhardt, J. William Smith,

THE SChOOL OF MACHINE DESIGN.-In point of numbers the condition of the school continues satisfactory, the registration this session being larger than ever before. The increase has been in the courses in mathematics, the technical courses, for which these are a preparation, showing a slight decrease.

Most of the students taking up the preparatory work are doing so with the object of qualifying for the more advanced courses; but it is our experience that many of these find the continued night work, after a day's labor, a too severe stress on their powers of endurance and are unable to continue. In consequence, the technical classes are largely made up of men who have obtained their mathematical training from outside sources, and this training frequently proves inadequate to properly carry on the work in hand. Our advanced classes have, therefore, always been small and are likely to continue so. Much diligence and great interest have been shown in all divisions of the course, and the students are to be congratulated on their persistent and painstaking efforts, which, judging from the progress made, cannot fail to be of lasting benefit to them and to reflect credit upon the school.

The class in algebra has been in charge of Mr. L. M. Arkley, and I am indebted to his care and skill for its prosperous condition.

\section{LUCIEN E. PICOLET,}

Director.

The Following Have Completed the Fuld Course and are AWARDED CERTIFICATES:

M. M. Borden,

W. J. Thompson, 
The FrankLIN INSTiTute School of Naval ARChitecturH.-I have the honor to report that the School of Naval Architecture has met with substantial increase in its enrollment over last year, and that the average attendance of the senior division students during the winter term was 98 per cent., and for the spring term 98.6 per cent., the majority of this division making the full attendance; that of the junior division was $92: 2$ per cent. for the winter term and $9 \mathrm{I} \cdot 6$ per cent. for the spring term. Nine of the senior division have attended the full term of two years and, having passed the examinations, will be graduated.

The senior class in Practical Naval Architecture has studied the various details in construction of the different classes of vessels, making sketches and calculations for the same. In Theoretical Naval Architecture they have calculated weights of material, centers of gravity, strength of structure of the hull under varied conditions, trim, stability, etc. Their hotne work has shown wonderful energy, considering that the drawings, etc., are made without the usual adjuncts of a drawing office. In fact, this class has exhibited more than ordinary intelligence and its members are above the average, being neat and painstaking.

The junior students have progressed rapidly in both theoretical and practical naval architecture, and have also shown marked zeal in their work in class and at home. Numerous drawings beyond the average in neatness and accuracy have been made from blue-prints lent for that purpose.

The class is indebted to the following gentlemen for donating valuable prizes for attendance, home work and examinations: Mr. C. H. Cramp, President of the Wm. Cramp \& Sons, shipbuilders and engineers, Philadelphia, Pa. Mr. Clement A. Griscom, President of the International Navigation Company, Philadelphia, Pa.; Mr. H. W. Morse, President of the New York Shipbuilding Company, Camden, N. J.; Mr. Lewis Nixon, President of the United States Shipbuilding Company, New York City.

Mr. C. H. Cramp has also offered a special prize to the apprentices employed by his firm who are students of this school and show marked effciency in home work and examinations, as well as paying the fees of those who pass the examination at the end of each term.

New York City, April I7, 1903.

ALEX. J. MaClean, Director.

The Following Students are Awarded Certificates:

John Sutton, Augustus Walko, C. Chesley,

Sam'1 H. MacDowell,
J. Wilber Yeats,

C. D. Wallach, Harold Elfreth, Lionel Levy, 